spans of species and the final doubling numbers of their cultured cells more obscure.

Commonwealth Serum Laboratories,

Jean Ferguson Stanley

DAVID PYE

ANDrew MaCGregor

Parkville, Victoria 3052, A ustralia

Received December 3, 1974; accepted March 27, 1975.

1 Hayflick, L., Expl Cell Res., 37, 614 (1965).

2 Hayflick, L., Am. J. med. Sci., 365, 432 (1973).

Eagle, H., Oyama, V. I., Levy, M., Horton, C. L., and Fleischman, R., J. biol. Chem., 218, 607 (1956)

Comfort, A., Ageing: The Biology of Senescence (Holt, Rinehart and Winston, New York, 1964).

5 Biology Data Book, 1 (Fedn. Am. Soc. expl. Biol., Bethesda, 1972)

6 Collins, L. R., Monotremes and Marsupials (Smithsonian, Washington, 1973).

7 Martin, G. M., Sprague, C. A., and Epstein. C. J., Lab. Invest., 23, 86 (1970).

\section{Heat-labile enzymes in Werner's syndrome fibroblasts}

RECENT reports indicate ${ }^{1,2}$ that cultured skin fibroblasts from subjects with Werner's syndrome, a hereditary disease of premature ageing ${ }^{3}$, have an increased proportion of heatlabile glucose-6 phosphate dehydrogenase (G-6PD) compared with normal cells undergoing ageing in vitro ${ }^{1,2,4}$. Additionally, two HL-A antigens show profoundly altered reactivities with specific antisera ${ }^{2}$, which in total demonstrates that three diverse gene products are markedly abnormal in Werner's fibroblasts. The purpose of our study was to document further this phenomenon in Werner's cells. We now report a high heat-labile fraction of 6-phosphogluconate dehydrogenase (6-PGD), an enzyme involved in the hexose monophosphate shunt, and hypoxanthine-guanine phosphoribosyltransferase (HGPRT), an enzyme concerned with purine metabolism.

Table 1 Heat-labile fraction of enzymes in cultured fibroblasts from a subject with Werner's syndrome and controls

$\%$ Heat-labile enzyme
$\begin{gathered}\text { 6-Phosphogluconate } \\ \text { dehydrogenase }\end{gathered}$
$\begin{aligned} & \text { Hypoxanthine- } \\ & \text { guanine } \\ & \text { phosphoribo- } \\ & \text { syltransferase }\end{aligned}$

$\begin{array}{lcc}\text { Werner's syndrome } & & \text { syltransferase } \\ \text { Experiment 1 } & 14 & 50 \\ \text { Experiment 2 } & 24 & 36 \\ \begin{array}{c}\text { Experiment 3 } \\ \text { Controls } \\ \text { Early passage }\end{array} & - & 40 \\ \text { Late passage } & 0.80 \pm 0.43 & 7.66 \pm 1.70 \\ & (n=10, \text { range } 0-4) & (n=9, \text { range 0-14) } \\ & (n=12, \text { range } 0-9) & (n=7, \text { range 15-32) }\end{array}$

Werner's cells were within 3-6 mean population doublings (MPD) of termination in a total replicative life span of $18 \mathrm{MPD}$; the limited number of experiments was dictated by the poor growth of these cells and finally exhaustion of their supply. Control values (mean \pm s.e.m.) represent experiments on strains of cultured cells from five normal donors aged 27-76 yr. Early passage cells were in the first third of their replicative life spans whereas late passage cells were within 0-9 MPD of growth termination (range of life spans 44-70 MPD). Werner's values are significantly different from late passage controls, $P<0.01$. Controls at late passage were significantly different from early passage controls, $P<0.01$.

Cultures were derived and propagated as described previous$1 y^{2}$. The assays for 6-PGD and HGPRT and the estimates of heat lability, which were accurate within $3-4 \%$, were carried out as before ${ }^{4,7}$. Control strains were studied at early and late passage, the latter serving as more suitable controls for the poorly growing Werner's cells.

Table 1 indicates that normal fibroblasts accumulated an increased fraction of heat-labile 6-PGD and HGPRT during the culture life span. But Werner's cells clearly contained a higher proportion of heat-labile enzyme, even when compared to control fibroblasts at late passage. Mixing experiments with equal parts of crude extracts from Werner's and control strains gave approximately intermediate heat-labile fractions suggesting that neither proteolysis nor a deficiency of stabilising factors was responsible for the results observed in Werner's cells $\mathbf{1}^{\mathbf{1 , 2 , 4} 7}$. The high heat-labile fraction of HGPRT in late-passage controls considerably exceeds that of 6-PGD and previous data on G-6PD ${ }^{1,2}$ for reasons that are uncertain but which probably relate to loss of the stabilising cofactor during the dialysis performed before HGPRT assay?

The data indicate that 6-PGD, an enzyme coded for by an autosomal gene and the X-linked $\mathrm{HGPRT}^{7}$ are markedly abnormal in Werner's fibroblasts at the same time as alterations appear in G-6PD and HL-A antigens, genetic loci that are also $\mathrm{X}$-linked and autosomal, respectively ${ }^{6,7}$. The results also show an increasingly defective fraction of 6-PGD and HGPRT in normal cells during ageing in vitro, as was found earlier for 6-PGD and G-6PD ${ }^{1,2,4,7,8}$. Indeed, similar abnormalities of the identical gene products have now been demonstrated in cultured cells derived from subjects with progeria, a related disorder of premature ageing ${ }^{5-8}$. The molecular nature of these defects is unclear and may even be unique in each case ${ }^{7,8}$. It is also not certain whether defective proteins are the consequence rather than the cause of cellular ageing. But these observations taken together with the decreased replicative potential that occurs during normal ageing ${ }^{6,9,10}$ and the more severe growth limitation observed in Werner's and progeria fibroblasts ${ }^{6,10}$, strengthen the view that the rate of fibroblast ageing in vitro is directly related to the rate of ageing in vivo ${ }^{1,2,4-10}$.

This work was supported by grants from the Medical Research Council of Canada and the Canadian Diabetic Association Foundation Fund during the tenure of a scholarship from the MRC (to S.G.).

\section{S. GoldDSTEIN \\ E. J. MOERMAN}

Departments of Medicine and Biochemistry,

McMaster University Medical Centre,

Hamilton, Ontario, Canada L8S $4 J 9$

Received January 24; accepted April 4, 1975.

${ }^{1}$ Holliday, R., Porterfield, J. S., and Gibbs, D. D., Nature, 248, 762 (1974).

2 Goldstein, S., and Singal, D. P., Nature, 251, 719 (1974).

Epstein, C. J., Martin, G. M., Schultz, A. L., and Motulsky, A. G., Medicine, 45, 177 (1966).

4 Holliday, R., and Tarrant, G. M., Nature, 238, 26 (1972),

5 Singal, D. P., and Goldstein, S., J. clin. Invest., 52, 2259 (1973).

6 Goldstein, S., Niewiarowski, S., and Singal, D. P., Fedn Proc., 34, 56 (1975).

Goldstein, S., and Moerman, E. J., New Engl. J. Med. (in the press)

Goldstein, S., and Moerman, E. J., Gerontologia (in the press).

${ }^{9}$ Hayflick, L., Expl Cell Res., 37, 614 (1965).

10 Martin, G. M., Sprague, C. A., and Epstein, C. J., Lab. Invest., 23, 86 (1970)

\section{Morphine abstinence is associated with increased brain cyclic AMP}

THE finding that theophylline, which inhibits brain cyclıc AMP phosphodiesterase ${ }^{1}$, produces a "quasi-morphine abstinence syndrome" that is intensified by naloxone and suppressed by heroin ${ }^{2}$ suggested that the real morphine abstinence syndrome may be associated with increased activity of a brain cyclic nucleotide. A suitable phosphodiesterase inhibitor would therefore heighten and a stimulant of phosphodiesterase would lower the intensity of real morphine abstinence signs. To test this, we administered such drugs to morphine-dependent rats shortly before withdrawal was precipitated with naloxone, so that the drugs would act only during the expression of abstinence. As these experiments indicated that the abstinence syndrome is largely associated with increased cyclic nucleotide activity, we attempted to identify the nucleotide by intracerebroventricular injection of cyclic nucleotides. These experiments indicated that cyclic AMP rather than cyclic GMP was primarily involved.

Opiate dependence was induced in male white Wistar rats $(100-150 \mathrm{~g})$ by a single subcutaneous injection of morphine, $150 \mathrm{mg} \mathrm{kg}^{-1}$, in a sustained-release preparation ${ }^{3}$. Withdrawal was precipitated $24 \mathrm{~h}$ later with 0.1 or $1 \mathrm{mg} \mathrm{kg}^{-1}$ subcutaneous 